\author{
JURNAL EINSTEIN \\ Jurnal Hasil Penelitian Bindang Fisika \\ Available online http://jurnal.unimed.ac.id/2012/index.php/inpafi \\ e-issn: $2407-747 x$, p-issn $2338-1981$
}

\title{
UJI KELAYAKAN AIR TELAGA ABADI BERDASARKAN BAKU MUTU AIR DENGAN PARAMETER FISIKA DAN PARAMETER KIMIA DI DESA SIUNONG-UNONG JULU KECAMATAN BAKTIRAJA KABUPATEN HUMBANG HASUNDUTAN
}

\author{
Fransiska T.D.Purba dan Mukti Hamjah Harahap \\ Jurusan Fisika, Fakultas Matematika dan Ilmu Pengetahuan Alam, Universitas Negeri \\ Medan, Indonesia \\ fransiskaprb1907@gmail.com \\ Diterima September 2017; Disetujui Oktober 2017; Dipublikasikan November 2017
}

\begin{abstract}
ABSTRAK
Penelitian yang telah dilakukan bertujuan untuk mengetahui kualitas air dan kelayakan air telaga abadi sebagai air minum di desa Siunong-unong Julu Kecamatan Baktiraja Kabupaten Humbang Hasundutan. Kelayakan air telaga abadi untuk air minum didasarkan pada baku mutu air yang telah ditetapkan oleh PERMENKES 416/MENKES/PER/IX/1990. Metode yang digunakan adalah mengukur daya hantar listrik dengan konduktivitimeter sebagai Parameter Fisika, kandungan mineral air dengan Parameter Kimia di BTKLPP Medan, dan kandungan besi dalam air di BARISTAN Medan. Penentuan kualitas air telaga abadi didasarkan pada baku mutu air yang telah ditetapkan oleh pemerintah yaitu PERMENKES 416/MENKES/PER/IX/1990 tentang Persyaratan Kualitas Air Tanah untuk Air Minum. Sampel penelitian diambil 11 titik di sekitar lokasi Air Telaga Abadi. Hasil penelitian parameter Fisika, yaitu kekeruhan dan suhu terdapat 1 sampel yang tidak layak memenuhi baku mutu air minum karena kekeruhannya melewati ambang batas dari 5 NTU , yaitu nilainya 6,87 NTU. Nilai DHL jika dikaitkan dengan Teori Davis, semua sampel air telaga abadi masih memenuhi baku mutu dengan nilai tertinggi 140,56 $\mu \mathrm{mhos} / \mathrm{cm}, 25^{\circ} \mathrm{C}$. Dan hasil penelitian parameter Kimia, yaitu $\mathrm{pH}$, Nitrat, kesadahan, klorida, TDS, besi $(\mathrm{Fe})$ semua sampel air telaga abadi telah memenuhi baku mutu air minum menurut PERMENKES 416/MENKES/PER/IX/1990 tentang Persyaratan Kualitas Air Tanah untuk Air Minum.
\end{abstract}

Kata Kunci : Kualitas air, Air Tanah, Parameter Fisika, Parameter Kimia

PENDAHULUAN

Air merupakan zat kehidupan, dimana tidak satupun makhluk hidup di planet bumi ini yang tidak membutuhkan air. Namun demikian perlu disadari bahwa keberadaan air di muka bumi ini sangat terbatas menurut ruang, dan waktu baik secara kuantitas maupun secara kualitas. Air bersih yang memenuhi syarat kesehatan harus bebas dari pencemaran, sedangkan air minum harus memenuhi standar yaitu persyaratan fisik, kimia dan biologis, karena air minum yang tidak memenuhi standar kualitas dapat menimbulkan gangguan kesehatan(Boekoese, 2010).

Sebagai negara yang alamnya kaya mineral, air tanah di Indonesia sering. Di dalam 
air kedua logam ini selalu ada bersama-sama. Bagi manusia kedua logam adalah esensial tetapi juga toksik. Keberadaannya dalam air tidak saja dapat dideteksi secara laboratories tetapi juga dapat dikenali secara organoleptik. Dengan konsentrasi $\mathrm{Fe}$ atau $\mathrm{Mn}$ sedikitnya $1 \mathrm{mg} / \mathrm{L}$, air terasa pahit-asarn, berbau tidak enak dan berwarna kuning kecoklatan (Lee, 1990).

Berdasarkan hal tersebut, maka perlu dilakukan penelitian mengenai uji kelayakan air telaga abadi berdasarkan baku mutu air dengan parameter fisika dan parameter kimia di desa Siunongunong Julu.

\section{METODE PENLITIAN}

Penelitian ini dilakukan dengan metode survey dengan pengambilan data melakukan studi lapangan dan metode eksperimen serta mengukur Daya Hantar Listrik. Studi lapangan berupa pengambilan data dilakukan di daerah air telaga abadi yang berada di desa Siunong-unong Julu. Dalam pengambilan sampel dilakukan penentuan titik sampel. Setelah itu menentukan parameter-parameter yang akan diuji dan dianalisa data.Pada pengolahan data nilai DHL pada sampel dilakukanpada suhu yang sama yaitu $25^{\circ} \mathrm{C}$. Untuk mendapatkan nilai DHL pada suhu $25^{\circ} \mathrm{C}$ maka dilakukan interpolasi linier dengan menggunakan persamaan :

$$
D H L\left(\mu \text { mhos } / \mathrm{cm}, 25^{\circ} C\right)=\frac{25}{t_{\text {air }}} D H L_{p}
$$

Dengan : $\quad$ tair $=$ Suhu air $\left({ }^{\circ} \mathrm{C}\right)$ $D H L_{p}=$ DHL pengukuran $(\mu \mathrm{mho} / \mathrm{cm})$

Hasi penelitian parameter fisika ditampilkan pada tabel 1 .

Tabel 1. Hasil penelitian parameter fisika

\begin{tabular}{|c|c|c|c|c|c|}
\hline \multirow[t]{2}{*}{$\begin{array}{c}\text { Kode } \\
\text { samp } \\
\text { el }\end{array}$} & \multirow[t]{2}{*}{$\begin{array}{c}\text { Jara } \\
\mathrm{k} \\
(\mathrm{m})\end{array}$} & \multirow{2}{*}{$\begin{array}{c}\text { Keda } \\
\text { lama } \\
\mathrm{n} \\
(\mathrm{m})\end{array}$} & \multicolumn{3}{|c|}{$\begin{array}{c}\text { Parame } \\
\text { ter } \\
\text { Fisika }\end{array}$} \\
\hline & & & $\begin{array}{c}\text { DHL( } \\
\text { pmhos / } \\
\text { cm) }\end{array}$ & $\begin{array}{c}\text { Suhu( } \\
\left.{ }^{\circ} \mathrm{C}\right)\end{array}$ & $\begin{array}{c}\text { Kek } \\
\text { eru } \\
\text { han } \\
\text { (NT } \\
\text { U) }\end{array}$ \\
\hline TA1 & 2 & 10 & 74,2 & 26,7 & 6,87 \\
\hline TA2 & 1,5 & 20 & 76,0 & 26,8 & 1,23 \\
\hline TA3 & 2 & 32 & 74,8 & 27,7 & 0,83 \\
\hline TA4 & 2,5 & 65 & 73,7 & 27,3 & 0,38 \\
\hline
\end{tabular}

\begin{tabular}{cccccc} 
TA5 & 3 & 74 & 74,0 & 27,2 & 0,63 \\
TA6 & 1,5 & 60 & 74,5 & 26,8 & 0,71 \\
TA7 & 1,2 & 55 & 75,9 & 26,4 & 0,53 \\
TA8 & 1 & 62 & 75,3 & 26,4 & 0,59 \\
TA9 & 5 & 63 & 75,0 & 26,4 & 0,09 \\
TA10 & 6 & 30 & 149,0 & 26,5 & 3,42 \\
TA11 & 20 & 50 & 139,8 & 25,5 & 4,63 \\
& & & & & \\
\hline
\end{tabular}

Hasil yang diperlihatkan dari tabel 1 pengujian sampel air telaga abadi di Desa Siunong-unong Julu Kecamatan Baktiraja Kabupaten Humbang Hasundutan adalah untuk menentukan parameter fisika berupa DHL (Daya Hantar Listrik), suhu , dan kekeruhan.

Jika diperhatikan seluruh sampel dalam keadaan suhu yang memenuhi baku mutu air minum. Rata-rata suhu seluruh sampel adalah $26,7^{\circ} \mathrm{C}$

Daya hantar listrik larutan elektrolit dipengaruhi oleh banyaknya ion-ion yang terdapat di dalam larutan tersebut. Semakin banyak jumlah ion yang ada dalam larutan maka semakin besar daya hantar listriknya. Larutan elektrolit juga dapat menghantarkan listrik. Pembawa muatan dapat berupa elektron seperti logam. Maka hal ini berhubungan juga dengan hasil analisa kandungan besi $(\mathrm{Fe})$.

Nilai kekeruhan air telaga abadi dari hasil pengambilan sampel di Desa Siunongunong Julu yaitu berkisar 0,09-6,87 NTU. Sampel yang memiliki nilai kekeruhan terendah berada pada sampel TA9 yaitu dengan nilai kekeruhan sebesar 0,09 NTU. Sampel yang memiliki nilai kekeruhan tertinggi berada pada sampel TA1 yaitu dengan nilai kekeruhan sebesar 6,87 NTU dikarenakan benda-benda halus yang ada di dalam air, serta produk buangan atau sampah masyarakat. Dan menurut baku mutu air, kekeruhan pada sampel TA1 tidak memenuhi baku mutu air minum.

Tabel 2. Parameter kimia penentu kualitas air tanah untuk air minum (Peraturan. Menteri Kesehatan Nomor 416 tahun 1999).

\begin{tabular}{lllll}
\hline No. & Unsur & Batas & Hasil & Keterangan \\
& Kimia & Maksimum & Analisa & \\
& & & Rata- & \\
& & & rata & \\
& & & 7,6 & Layak
\end{tabular}


Fransiska T.D.Purba, Mukti Hamjah Harahap: Uji Kelayakan Air Telaga Abadi Berdasarkan Baku Mutu Air Dengan Parameter Fisika dan Parameter Kimia di desa Siunongunong Julu Kecamatan Baktiraja Kabupaten Humbang Hasundutan

\begin{tabular}{|c|c|c|c|c|}
\hline 2. & Nitrat & $50 \mathrm{mg} / \mathrm{l}$ & $\begin{array}{l}<0,5 \\
\mathrm{mg} / 1\end{array}$ & Layak \\
\hline 3. & Kesadahan & $500 \mathrm{mg} / \mathrm{l}$ & $\begin{array}{l}175,6 \\
\mathrm{mg} / \mathrm{l}\end{array}$ & Layak \\
\hline 4. & Klorida & $250 \mathrm{mg} / \mathrm{l}$ & $\begin{array}{l}3,112 \\
\mathrm{mg} / \mathrm{l}\end{array}$ & Layak \\
\hline 5. & TDS & $500 \mathrm{mg} / \mathrm{l}$ & $\begin{array}{l}301 \\
\mathrm{mg} / \mathrm{l}\end{array}$ & Layak \\
\hline 6. & Besi & $0,3 \mathrm{mg} / \mathrm{l}$ & $\begin{array}{l}0,2 \\
\mathrm{mg} / 1\end{array}$ & Layak \\
\hline
\end{tabular}

Hasil penelitian terhadap sampel air telaga abadi di Desa Siunong-unong Julu yang memiliki nilai kesadahan ( $\mathrm{CaCo} 3)$ yang berkisar antara 172,0-204,0 $\mathrm{mg} / \mathrm{l}$ dan masih beradadi bawah ambang batas maksimum yang diperbolehkan yaitu 500mg.

Dari hasil penelitian terhadap sampel air telaga abadi di Desa Siunong-unong Julu memiliki nilai Klorida $(\mathrm{Cl})$ yang berkisar antara 1,500-4,249 mg/l dan masih berada di bawah ambang batas maksimum yang diperbolehkan yaitu $250 \mathrm{mg} / \mathrm{l}$.

Hasil penelitian terhadap sampel air telaga abadi di Desa Siunong-unong Julu memiliki nilai TDS (Zat Padat Terlarut) yang berkisar antara 48-415 mg/l dan masih berada di bawah ambang batas maksimum yang diperbolehkan yaitu $500 \mathrm{mg} / \mathrm{l}$. Jika disajikan dalam bentuk grafik maka akan terlihat seperti gambar 9 berikut ini.

Dari hasil penelitian terhadap sampel air telaga abadi di Desa Siunong-unong Julu diperoleh bahwa memiliki nilai kandungan Besi(Fe) yang berkisar antara $<0,023-0,11 \mathrm{mg} / \mathrm{l}$ dan masih berada di bawah ambang batas maksimum yang diperbolehkan yaitu $0,3 \mathrm{mg} / \mathrm{l}$.

\section{HASIL DAN PEMBAHASAN}

Setelah dilakukan pengambilan data dengan menggunakan alat geolistrik (Resistivity Meter), ARES-G4 v4,7 SN: 0609135 (Autematic Resistivity System), GPS (Global Position System), di kedua lintasan yang telah ditentukan kemudian dilakukan pengunduhan data maka didapatkan hasil data tentang resistivitas dari tiap-tiap titik, kemudian data tersebut dikalikan dengan faktor geometri (konfigurasi Schumberger) umtuk mendapatkan nilai resistivitas semu 『( $\left.\rho \rrbracket \_s\right)$ yang akan digunakan dalam membuat kontur dengan menghubungkan tiap-tiap nilai resistivitas semu $\llbracket\left(\rho \rrbracket \_s\right)$ tersebut maka diperoleh data sebagai berikut :

Tabel 2. Nilai setiap koordinat lintasan

\begin{tabular}{|c|c|c|c|c|}
\hline Lintasan 1 & $\begin{array}{l}\text { Waktu } \\
\text { (WIB) }\end{array}$ & ALT & Posisi & $\begin{array}{l}\text { Resistivitas } \\
\text { Semu }(\Omega \mathrm{m})\end{array}$ \\
\hline Letak Geolistrik & 08.56 & $18 \mathrm{~m} \mathrm{dpl}$ & $\begin{array}{l}\text { N } 02^{\circ} 2^{\prime} 27.30^{\prime \prime \prime} \\
\text { E } 98^{\circ} 21^{\prime} 3.16^{\prime \prime}\end{array}$ & \multirow{3}{*}{$4,84-105 \Omega \mathrm{m}$} \\
\hline Elektroda 1 & 08.53 & $18 \mathrm{~m} \mathrm{dpl}$ & $\begin{array}{l}\text { N } 02^{\circ} 2^{\prime} 28.50^{\prime \prime} \\
\text { E } 98^{\circ} 21^{\prime} 0.61^{\prime \prime}\end{array}$ & \\
\hline Elektroda 32 & 08.58 & $16 \mathrm{~m} \mathrm{dpl}$ & $\begin{array}{l}\text { N } 02^{\circ} 2^{\prime} 25.51^{\prime \prime} \\
\text { E } 98^{\circ} 21^{\prime} 5.24^{\prime \prime}\end{array}$ & \\
\hline Lintasan 2 & $\begin{array}{l}\text { Waktu } \\
\text { (WIB) }\end{array}$ & ALT & Posisi & $\begin{array}{l}\text { Resistivitas } \\
\text { Semu }(\Omega \mathrm{m})\end{array}$ \\
\hline Letak Geolistrik & 11.11 & $14 \mathrm{~m} \mathrm{dpl}$ & $\begin{array}{l}\text { N } 02^{\circ} 2^{\prime} 23.65^{\prime \prime} \\
\text { E } 98^{\circ} 21^{\prime} 7.81^{\prime \prime}\end{array}$ & \multirow{3}{*}{$0,865-165 \Omega \mathrm{m}$} \\
\hline Elektroda 1 & 11.09 & $20 \mathrm{~m} \mathrm{dpl}$ & $\begin{array}{l}\text { N } 02^{\circ} 2^{\prime} 25.51^{\prime \prime} \\
\text { E } 98^{\circ} 21^{\prime} 5.24^{\prime \prime}\end{array}$ & \\
\hline Elektroda 32 & 11.16 & $16 \mathrm{~m} \mathrm{dpl}$ & $\begin{array}{l}\mathrm{N} 02^{\circ} 2^{\prime} 22.02^{\prime \prime \prime} \\
\mathrm{E} 98^{\circ} 21^{\prime} 9.32^{\prime \prime}\end{array}$ & \\
\hline
\end{tabular}

Tampilan 2-D hasil dari pengelolahan data dengan Res2Dinv tersebut terdiri dari tiga kontur Isoresistivitas pada penampang kedalaman semu (Pseudodepth section). Penampang yang pertama menunjukkan kontur resistivitas semu pengukuran (measured apparent resistivity), yaitu data resistivitas dari hasil perhitungan (calculated apparent resistivity), dan penampang yang ketiga adalah kontur resistivitas yang sebenarnya yang diperoleh setelah melalui proses pemodelan inversi (inversi model resistivity section).

Pada Lintasan Pertama data yang diperoleh dengan menggunakan alat Geolistrik (Restivity Meter) adalah nilai resistivitas semu bervariasi karena struktur bawah tanah sangat bervariasi, nilainya berkisar antara 4,84 $\Omega \mathrm{m}$ sampai dengan $105 \Omega \mathrm{m}$. Pada panjang lintasan 155 meter dengan jarak tiap elektroda 5 meter setelah diinversikan dengan Software Res2Dinv diperoleh gambar penampang seperti gambar 2 . di bawah : 


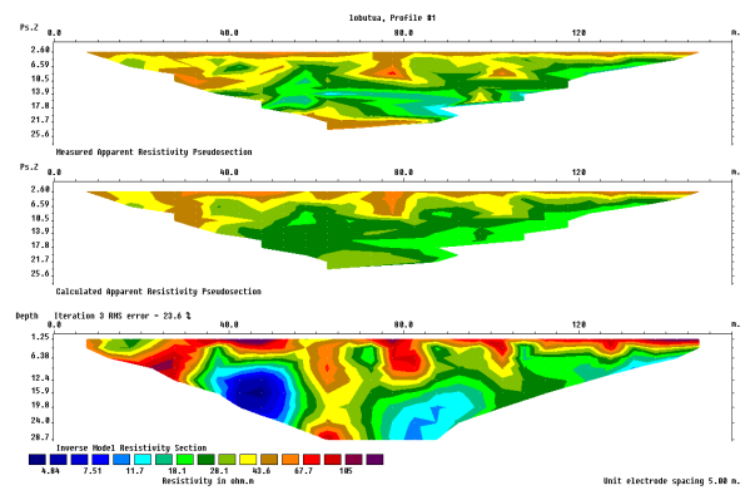

Gambar 2. Penampang Kontur Resistivitas Pertama

Berdasarkan penampang kontur resistivitas pada lintasan pertama, setiap warna memiliki nilai resistivitas yang berbeda. Warna biru pada kedalaman 9,39 meter sampai 24,0 meter menandakan nilai resistivitas yang rendah yaitu berkisaran antara $4,84-11,7 \Omega \mathrm{m}$, sedangkan warna hijau dan kuning pada kedalaman sekitar 3.81 meter sampai 28,7 meter, nilai resistivitasnya semakin tinggi dari nilai sebelumnya yaitu berkisar antara $18,1-43,6 \Omega \mathrm{m}$, dan warna merah dan ungu menandakan nilai resistivitas tertinggi pada setiap gambar penampang berkisar antara 67,7 - $105 \Omega \mathrm{m}$. Maka jenis tanah/batuan lapisan penyusun dapat diinterpretasikan seperti pada tabel 3 .

Tabel 3. Interpetrasi Lintasan Pertama

\begin{tabular}{cccc}
\hline No & $\begin{array}{c}\text { Kedalaman } \\
(\mathrm{m})\end{array}$ & $\begin{array}{c}\text { Resistivitas } \\
(\mathrm{m})\end{array}$ & Interpretasi \\
\hline 1. & $1,25-9,39$ & $67,7-105$ & Tanah liatLempung \\
2. & $9,39-24,0$ & $4,84-11,7$ & Tanah lanau lembek \\
3. & $3,81-28,7$ & $18,1-43,6$ & Tanah liatLempung \\
\hline
\end{tabular}

Berdasarkan tabel 2. pada kedalaman 1,25 meter sampai 28,7 meter belum terdeteksi lapisan keras dan struktur batuan pada bawah permukaan tanah. Seperti yang telah ditunjukkan dengan warna merah dan ungu yang terdapat pada lapisan permukaan atas pada kedalaman 1,25 meter sampai 9,39 meter yang memiliki nilai resistivitas 67,7 - $105 \Omega \mathrm{m}$ merupakan tanah liat/lempung bercampur dengan pasir (berdasarkan tabel 2.3) yang merupakan hasil pemadatan pondasi dari masyarakat sekitar. Sementara pondasi suatu bangunan dinyatakan layak apabila terdapat lapisan batuan dasar berkekar terisi tanah kering dengan nilai resistivitas lebih dari 300
$\Omega$ m kemudian dilakukan pemadatan tanah agar mendapat tekstur lapisan tanah yang kuat untuk pondasi dari suatu bangunan (Syamsurizal dkk, 2013). Daerah penelitian ini memiliki nilai resistivitas sangat rendah, dikarenakan daerah penelitian merupakan daerah pesisir dan pori-pori batuan terisi air laut yang merupakan larutan konduktif.

Pada Lintasan Kedua data yang diperoleh dengan menggunakan alat Geolistrik (Restivity Meter) adalah nilai resistivitas semu bervariasi karena struktur bawah tanah sangat bervariasi, nilainya berkisar antara $0,856 \Omega \mathrm{m}$ sampai dengan 165 $\Omega \mathrm{m}$. Pada panjang lintasan 155 meter dengan jarak tiap elektroda 5 meter setelah diinversikan dengan Software Res2Dinv diperoleh gambar penampang seperti gambar 3. di bawah :

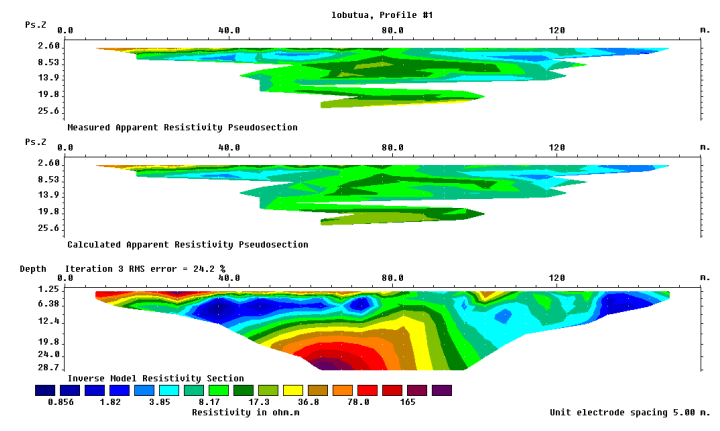

Gambar 3. Penampang Kontur Resistivitas Kedua

Berdasarkan penampang kontur resistivitas pada lintasan pertama, setiap warna memiliki nilai resistivitas yang berbeda. Warna biru pada kedalaman 1,25 meter sampai 16,1 meter menandakan nilai resistivitas yang rendah yaitu berkisan antara $0,856-3,85 \Omega \mathrm{m}$, sedangkan warna hijau dan kuning pada kedalaman sekitar 6,38 meter sampai 19,8 meter, nilai resistivitasnya semakin tinggi dari nilai sebelumnya yaitu berkisar antara 17,3-36,8 $\Omega \mathrm{m}$, dan warna merah dan ungu menandakan nilai resistivitas tertinggi pada setiap gambar penampang berkisar antara 78,0 - $165 \Omega \mathrm{m}$. Maka jenis tanah/batuan lapisan penyusun dapat diinterpretasikan seperti pada tabel 4 . 
Fransiska T.D.Purba, Mukti Hamjah Harahap: Uji Kelayakan Air Telaga Abadi Berdasarkan Baku Mutu Air Dengan Parameter Fisika dan Parameter Kimia di desa Siunongunong Julu Kecamatan Baktiraja Kabupaten Humbang Hasundutan

Tabel 4. Interpetrasi Lintasan Kedua

\begin{tabular}{cccc}
\hline No & $\begin{array}{c}\text { Kedalaman } \\
(\mathrm{m})\end{array}$ & $\begin{array}{c}\text { Resistivitas } \\
(\Omega \mathrm{m})\end{array}$ & Interpretasi \\
\hline 1. & $1,25-16,1$ & $0,856-3,85$ & Tanah lanau lembek \\
2. & $6,38-19,8$ & $17,3-36,8$ & Tanah liat/Lempung \\
3. & $19,8-28,7$ & $78,0-165$ & $\begin{array}{c}\text { Batuan Dasar (Batuan } \\
\text { pasir) Lempung }\end{array}$ \\
\hline
\end{tabular}

Berdasarkan gambar 3. pada kedalaman 1,25 meter sampai 16,1 meter belum terdeteksi lapisan keras dan struktur batuan pada bawah permukaan tanah. Sementara pondasi suatu bangunan dinyatakan layak apabila terdapat lapisan batuan dasar berkekar terisi tanah kering dengan nilai resistivitas lebih dari 300 $\Omega m$ kemudian dilakukan pemadatan tanah agar mendapat tekstur lapisan tanah yang kuat untuk pondasi dari suatu bangunan (Syamsurizal dkk, 2013). Seperti yang telah ditunjukkan dengan warna merah dan ungu yang terdapat pada lapisan bawah pada kedalaman 19,8 meter sampai 28,7 meter yang memiliki nilai resistivitas 78,0 - $165 \Omega \mathrm{m}$ merupakan Batuan dasar berisi tanah lembek (berdasarkan tabel 2.3). Daerah penelitian ini memiliki nilai resistivitas sangat rendah, dikarenakan daerah penelitian merupakan daerah pesisir dan pori-pori batuan terisi air laut yang merupakan larutan konduktif.

\section{KESIMPULAN DAN SARAN}

Dari hasil penelitian yang dilakukan dapat dibuat kesimpulan bahwa kualitas air telaga abadi berdasarkan parameter fisika memiliki daya hantar listrik berkisar 67,49$140,56 \mu \mathrm{mhos} / \mathrm{cm}, 25^{\circ} \mathrm{C}$, namun menurut kekeruhannya bahwa sampel TA1 tidak layak untuk diminum karena telah melewati batas ambang baku mutu air minum dengan nilai 6,87 NTU. Dan berdasarkan parameter kimia semua air telaga abadi di Desa Siunongunong Julu masih memenuhi standar baku mutu air minum sesuai dengan

PERMENKES 416/MENKES/PER/IX/1990 tentang Persyaratan Kualitas Air Tanah untuk Air Minum. Baku mutu air minum berdasarkan peraturan Menteri Kesehatan RI No. 416/ Menkes/ Per/ IX/ 1990 dengan hasil penelitian telah dinyatakan layak dan memenuhi baku mutu air minum. Hasil penelitian berdasarkan baku mutu air dengan parameter kimia semua air telaga abadi di Desa Siunong-unong Julu masih memenuhi standar baku mutu air minum sesuai dengan PERMENKES 416/ MENKES / PER/ IX/ 1990 tentang Persyaratan Kualitas Air Tanah untuk Air Minum.

\section{DAFTAR PUSTAKA}

Atkins, P.W., (1999), Kimia Fisika Jilid II, Erlangga, Jakarta.

Boekoesoe L., (2010), Tingkat Kualitas Bakteriologis Air Bersih di Desa Sosial Kecamatan Paguyaman Kabupaten Bualemo, Jurnal Inovasi, ISSN 16939304.

Badan Penelitian dan Pengembangan Kesehatan, (2013), Riset Kesehatan Dasar (RISKESDAS) 2013, Kementerian Kesehatan Republik Indonesia.

[BPS] Badan Pusat Statistik, (2012), Humbahas dalam angka 2012, BPS Humbahas

Grace, (2014), Analisis Intrusi Air Laut dan Kandungan Logam Berat pada Air Sumur Gali dan Sumur Bor di Kecamatan Hamparan Perak.Skripsi, Unimed : Medan.

Hendrayana, Heru., (2002), Intrusi Air Asin Ke

Dalam Akuifer Di Daratan, (Online),

(http://heruhendrayana.staff.ugm.ac.id ) diakses 04 Juli 2017.

Lee, R., (1990), Hidrologi Hutan, Gadjah Mada University Press, Yogyakarta.

Linsley, R.K dan Franzini, J.B, (1991), Teknik Sumber Daya Air, Erlangga: Jakarta.

Notodarmojo, Suprihanto., (2005), Pencemaran Tanah dan Air Tanah, Bandung: ITB

Putranto, T.T., Kusuma, K.I., (2009), Permasalahan Air Tanah Pada Daerah Urban, Jurnal Teknik,2009:30:ISSN 052-1697.

Rosita, Nita., (2014), Analisis Kualitas Air Minum Isi Ulang Beberapa Depot Minum Isi Ulang (DAMIU) di Tangerang Selatan, Jurnal Kimia Valensi, Vol. 4. No. 2:134-141.

Rumila, H.M.T., (2013), Rekayasa Hidrologi, Unimed Press, Medan.

Sahwilaksa J., Indiah K., (2014), Pengaruh Air Laut Terhadap Kualitas Air Tanah Dangkal Di KawasanPantai Kota Surabaya, Vol. 3. No.10. 
Soemarto.,(1995), Hidrologi Teknik Ed 2, Erlangga, Jakarta.

Suharyadi, M.S., (2002), Pengantar Geologi Teknik Edisi 4, Yogyakarta: Teknik Sipil UGM.

Sunandar, A., (2009), Kualitas Air Tanah Di

Dataran Rendah Teluk Naga Kabupaten Tangerang, UI:FMIPA.

Suripin, M.Eng., (2001), Pelestarian Sumber Daya Tanah dan Air, Andi, Yogyakarta.

Todd, David, K., (1980), Groundwater Hydrology, John Wiley, New York.

Wardhana, (2008), Polutan Pencemaran Logam Berat, Makalah Kimia Lingkungan, PTKI.

Wardani,P.I., Wahyono, S.C., Ibrahim, S.,(2016), Pendugaan Air Tanah Dengan Metode Geolistrik Schlumberger Di Desa Takuti Kabupaten Banjar Kalimantan Selatan, Jurnal Fisika FLUX Vol.13.No.1, FMIPA, Universitas Lambung Mangkurat.

Wilson, E., (1993), Hidrologi TeknikEdisi Keempat, Bandung, ITB.

Wuryantoro, (2007), Aplikasi Metode Geolistrik Tahanan Jenis Untuk Menentukan Leta dan Kedalaman Aquifer Air Tanah di Desa Temperak Kecamatan Serang Kabupaten Rembang Jawa Tengah, Skripsi, FMIPA, UNNES, Semarang. 